\title{
Non-Librarians in the Academic Library
}

\begin{abstract}
This article explores some differences between a group of people working professionally in academic libraries who do not regard themselves as librarians and an individually matched group of librarians who do identify with the profession. The differences explored are: salaries, education (both professional and non-library), non-library associational affiliations, fulfillment of career expectations, and position classification. The results are regarded in terms of David Weber's article, "The Place of 'Professional Specialists' on the University Library Staff," which appeared earlier in College and Research Libraries.
\end{abstract}

$\mathrm{T}$ HERE EXISTS within the academic library a discernible group of people, usually holding specialized jobs, who choose to regard themselves as belonging, not to the library profession, but to some other profession or discipline. Some aspects of this group have been discussed by David C. Weber in his article "The Place of 'Professional Specialists' on the University Library Staff."1

A current survey of the characteristics of academic librarians being carried out by Anita R. Schiller at the University of Illinois library research center provides an opportunity to look at this group of other-than-librarians more closely. ${ }^{2}$ The Schiller study, through a systematic two-stage stratified probability sample, takes into account all professional personnel employed in academic libraries of all types in the United States. One out

1 David C. Weber, "The Place of "Professional Specialists' on the University Library Staff," CRL, XXVI (September 1965), 383-88.

2 Anita R. Schiller, "Characteristics of Professional Personnel in College and University Libraries" (unpublished research in progress at the University of Illinois, Library Research Center, Graduate School of Library Science).

$\mathrm{Mrs}$. Trumpeter is research associate, $\mathrm{Li}$ brary Research Center, Graduate School of Library Science, University of Illinois. of every five individuals so employed was asked to complete and return a questionnaire. There was a 92 per cent response rate from the 2,660 sampled librarians, 2,282 of whom were full-time workers.

The following question from this survey provided the data for the present analysis of some characteristics of this group of "non-librarian" professionals in academic libraries:

Do you regard yourself professionally as a: (check only one) ...... Librarian $\ldots .$. Other (specify)...........

In answering this question, fifty-six respondents specified "other," indicating that they perform professional tasks in an academic library but do not regard themselves as librarians. All were fulltime salaried workers.

These fifty-six people make up the principal group examined in this article (Group A). For comparative purposes, a second group was then chosen consisting of fifty-six people who do regard themselves professionally as librarians (Group B). Group B subjects were individually matched with Group A subjects for sex, age, length of contract year, and type, size, and control of institution 
employing them. A five-year range was allowed for matching on the age variable; on the other variables, subjects were identically matched.

Since Group A consisted of thirtyeight men and eighteen women, Group $B$ had the same composition. This distribution in itself is interesting when one realizes that within the entire population of academic librarians, the ratio is approximately two women to one man. For those respondents who work in academic libraries but do not consider themselves as librarians, this ratio is reversed. On other characteristics for the two groups, the median age of the men was fortyone years (ranging from twenty-five to sixty-seven) and of the women, fortythree years (ranging from twenty-five to sixty). The majority of the subjects (68 per cent) were employed in university libraries.

For exploratory purposes the following list of questions was devised to check against survey data for the two groups.

1. Is there a significant difference in the salaries received?

2. Is one group more likely to have professional library training than the other?

3. Is membership in non-library groups and associations more common in one group than the other?

4. Is there a difference in educational level as measured by the highest subject degree held?

5. Is there a difference in the way members of the two groups feel their careers have fulfilled their expectations?

6. Are members of one group more likely to hold a higher position classification in the library than those of the other group?

In order to test these questions, data were drawn from the larger survey on the following variables for the individual subjects of both groups: (1) salary; (2) library degree(s) held; (3) number of non-library associational affiliations; (4) highest subject degree held; (5) fulfillment of career expectations; and (6) library position level.

Actual salary and the number of nonlibrary group affiliations were recorded directly from the questionnaires. Library degree information was regarded as dichotomous; the individual either did or did not have professional library training. The highest subject (i.e., non-library) degree held was quantified as: (0) none, (1) bachelor's, (2) master's, and (3) doctorate. An ordinal scale was used to measure fulfillment of career expectations. It ran from one through five as follows: (1) very disappointing, (2) somewhat disappointing, (3) about as expected, (4) somewhat more satisfying than expected, and (5) much more satisfying than expected. The position classification levels were coded as follows: (1) professional assistant, (2) head of college, school, or departmental library, (3) department or division head, (4) associate or assistant director, and (5) chief librarian or director.

Appropriate statistical tests of significance were then performed in the comparison of the two groups. The t-test of difference between two means was applied to the salary information. Chisquare was used with the dichotomous library degree information. Other differences were tested for significance using the Mann-Whitney U-test. The predetermined level of significance was .01.

TABLE 1

Professional Library Training

\begin{tabular}{|c|c|c|c|c|}
\hline & \multicolumn{2}{|c|}{ Group A } & \multicolumn{2}{|c|}{ Group B } \\
\hline & No. & $\begin{array}{c}\text { Per } \\
\text { Cent }\end{array}$ & No. & $\begin{array}{c}\text { Per } \\
\text { Cent }\end{array}$ \\
\hline \multirow{2}{*}{$\begin{array}{l}\text { With library degree } \\
\text { Without library } \\
\text { degree }\end{array}$} & 13 & 24 & 44 & 80 \\
\hline & 42 & 76 & 11 & 20 \\
\hline Total & 55 & 100 & 55 & 100 \\
\hline
\end{tabular}


TABLE 2

MEMbERShIP IN Non-LibraRy Associations

\begin{tabular}{l|c|c|c|c}
\hline \hline & \multicolumn{2}{|c|}{ Grour A } & \multicolumn{2}{c}{ Grour B } \\
\cline { 2 - 5 } & No. & Per Cent & No. & Per Cent \\
\hline $\begin{array}{l}\text { Number belonging to no non-library } \\
\text { organizations }\end{array}$ & 12 & & & \\
$\begin{array}{l}\text { Number belonging to one non- } \\
\text { library organization }\end{array}$ & 19 & 38 & 33 & 66 \\
$\begin{array}{l}\text { Number belonging to two or more } \\
\text { non-library organizations }\end{array}$ & 19 & 38 & 9 & 18 \\
$\quad$ Total & 50 & 100 & 50 & 16 \\
\hline
\end{tabular}

\section{Results}

1. Statistically, there was no significant difference in the salaries earned by members of the two groups.

2. Subjects in Group A (those who consider themselves as other-than-librarians ) had less professional library training than Group B subjects and this difference was significant at the .01 level. Of the fifty-five subjects in each group for whom data were available, forty-four of those in Group B had professional library degrees, while only thirteen of those in Group A had such training (Table 1).

3. Subjects in Group A belonged to more professional non-library associations than did Group B subjects and this difference is significant at the .01 level (Table 2).

4. Subjects in Group A had attained a higher level of education as measured by highest (non-library) subject degree earned, and this difference is significant at the .01 level (Table 3 ).

TABLE 3

Highest Subject Degrees Earned

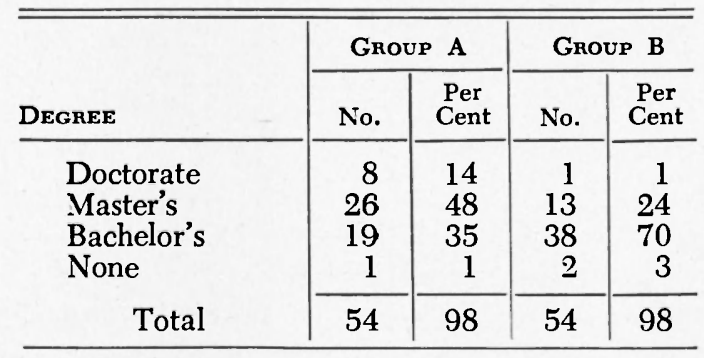

5. Statistically, there was no significant difference in the way subjects in the two groups felt their careers in academic libraries had fulfilled their expectations. Those who regarded themselves as librarians were just as likely to be satisfied (or disappointed) as were those who denied identification with the library profession.

6. Statistically, there was no significant difference in the position classifications held by members of the two groups. Individual subjects from both groups can be found at all position levels in the academic library.

\section{Discussion}

This analysis is concerned with a group of fifty-six academic library professional employees who identify themselves as other-than-librarians and with some ways in which they differ from an individually matched group who identify with the library profession. The writer is enough acquainted with the data bank from which these two groups were drawn to realize that there are many people on academic library staffs who could equally well qualify as professional specialists but who do regard themselves as librarians. From survey data it is clear, however, that this group of fiftysix who do not regard themselves professionally as librarians are realistic in their assessment and do, in fact, differ in several ways from the librarian group. All of the fifty-six subjects have the 
special education and previous work experience necessary to justify their identification with another professional group. Their occupational self-images, therefore, seem to be legitimate. Although a small proportion of the group ( 24 per cent) had library degrees, it is their other advanced degrees that form the basis for their difference from the professional librarian group. The non-librarians had attained higher levels of education as measured by the highest (non-library) subject degrees earned. In this group were eight subject doctorates and twenty-six subject master's degrees, compared to one subject doctorate and thirteen subject master's degrees among the matched group who regard themselves as librarians. This subject specialization makes all the more legitimate the identification which members of Group A claim with professions other than librarianship.

The two professions which were specified most often were audio-visual specialist and teacher. Of the eight teachers, six were women. Eight of the nine audio-visual specialists were men. (The number of people from Group A who identify with these two professions helps explain the popularity of membership in the National Education Association as mentioned below.) Other examples of the professional identification specified by the group of non-librarians were: archivist, historian, subject specialist, bibliographer, lawyer, chemist, artist, business manager, professor, photographic reproduction specialist, systems analyst, information scientist, and map specialist. This list calls to mind David Weber's list of "specific specialist assignments" in academic libraries. Weber defines a specialist as "an individual with a subject or technical expertise combined with a knowledge of libraries and educational institutions. . . . The term is further limited to persons whose specialist talents may be said to dominate his talents as a librarian."3

\footnotetext{
${ }^{3}$ Weber, op. cit., 383.
}

Weber seems to be describing the group of non-librarians studied here as he goes on to say that "an indication of the dominating interest in the specialty would be the individual's membership and activity in such associations as the Society of American Archivists, the National Microfilm Association, or the Modern Language Association, and perhaps little interest" in library associations. ${ }^{4}$ The present analysis shows that membership in non-library national associations is much more common among the non-librarians studied than among the librarians. Seventy-six per cent of the non-library group belong to one or more non-library associations while, of the librarians, 66 per cent do not belong to any non-library associations.

The list of non-library associations to which the non-librarians belong is long and revealing. The most popular are the National Education Association with thirteen members and the American Association of University Professors with eleven members. (In the latter organization, however, one can also find eight of the fifty-six Group B librarians.) Four of the non-librarian group belong to the Society of American Archivists and three to each of the following: American Historical Association, the Organization of American Historians, and the American Association of University Women. Represented among the remaining twentyseven associations specified by only one or two people were such groups as: the Renaissance Society, American Indian Ethnohistoric Conference, Keats-Shelley Association of America, the National Women Lawyers' Association, and the Society of Early Historical Archaeology. These less common associational affiliations are further evidence of this group's specialist interests.

With regard to fulfillment of career expectations and the position classifications held by members of the two groups, there is less evidence of substantial differences. In neither case were the dif-

\footnotetext{
4 Ibid., 384.
} 
ferences statistically significant. No one from either group declared himself "very disappointed" with the fulfillment of his career expectations. Both librarians and non-librarians were found to cluster at the midpoint which indicated that their library careers were "about as expected." Individuals in both groups were found in all position levels. Neither group was represented in one position more than another position.

Although the difference in salaries for the two groups was not found to be statistically significant, the professional significance becomes apparent when one recognizes the non-librarians as specialists. Weber suggests that a separate salary schedule is usually created because "the specialist is drawn from a different market which dictates the salary minimums for different levels."5 That this is not always the case for those specialists who do not regard themselves as librarians is apparent from the data. The following comment, appended to one questionnaire, emphasizes one notable exception:

Librarians are notoriously underpaid. For that reason I switched to being a systems analyst. I immediately received a boost of 25 per cent in salary with a promise of another 25 per cent in two years. This, by the way, was done at the same institution.

It happens that this person did have a library degree and had had previous work experience in a field allied to systems analysis. Since this is a specialty sought in a national market, it was financially expedient for him to change his occupational image and regard himself professionally as something other than a librarian.

The median salary for the non-li-

Ibid., 386. brarians as a group, however, was $\$ 9,000$ (mean $\$ 9,148$ ) as compared with the median for the librarians which was $\$ 8,450$ (mean $\$ 8,996$ ). As indicated earlier the majority (68 per cent) of people in both groups were found in university libraries. Of those employed in university libraries the median salary was $\$ 9,450$ for the non-librarians and $\$ 9,100$ for the librarians. The differences are clearly minor and were not statistically significant in any case. One would have to conclude that there are no real group advantages in salary for the non-librarian group.

In summary, the individuals who do not regard themselves professionally as librarians do, in fact, differ in several respects from their colleagues. Significant differences can be found with regard to library training, non-library associational affiliations, and level of education as measured by highest non-library subject degree held. Still, there appears to be little difference between the two groups with regard to salary, position level, and career satisfaction.

Library training, non-library associational affiliations, and level of education are some factors which seem to be quite strongly associated with the librarian-non-librarian dichotomy since they emerge in the small sample conditions of this study. If the sample of non-librarians had been larger and more representative, other more subtle differences might have emerged. Gathering data for another study which would focus on this dichotomy may be worthwhile. This analysis suggests, in general, that the non-librarians are well qualified in educational background and work experience for the specialist jobs they hold and that they are not receiving any particular salary advantage over the traditionally trained librarians. 